\title{
Occurrence of a Metacentric Macrochromosome B in Different Species of the Genus Astyanax (Pisces, Characidae, Tetragonopterinae)
}

\author{
Orlando Moreira-Filho ${ }^{1, *}$, Alberto Sergio Fenocchio ${ }^{2}$, \\ Maria Cristina Pastori ${ }^{2}$ and Luiz Antônio Carlos Bertollo ${ }^{1}$ \\ ${ }^{1}$ Universidade Federal de São Carlos. Departamento de Genética e Evolução. Caixa Postal 676. \\ 13565-905 São Carlos-SP. Brasil. \\ ${ }^{2}$ Universidad Nacional de Misiones. Facultad de Ciencias Exactas, Químicas y Naturales. \\ Departamento de Genética. Argentina.
}

Accepted December 16, 2000

\begin{abstract}
Summary Several cases of B chromosomes have been described for neotropical fish species. In some fish groups, this occurrence is sporadic, whereas in others it is more frequent. A high frequency of a metacentric macrochromosome B has been reported for Astyanax scabripinnis populations from different locations. In the present study, this kind of chromosome is reported for the first time in 2 other species of the same genus, A. fasciatus and A. schubarti. This coincidence, as well as the differential B chromosome frequency among the 3 Astyanax species, permit some considerations about its probable common origin and further distribution in this fish group.
\end{abstract}

Key words Pisces, Astyanax, B chromosomes.

According to Géry (1977), the genus Astyanax is the largest unit of Tetragonopterinae. It is one of the dominant fish groups in South America, that comprises more than 62 freshwater species and subspecies in Brazil. Garuti (1988) demonstrated that the genus is quite complex, with several closely related morphological forms.

The diploid number and/or karyotypic formula have been determined for 9 described species and for 10 unidentified species of this genus. They show as extensive diversity ranging from $2 n=36$ (A. schubarti) to $2 n=50$ (A. bimaculatus, A. taeniatus, A. scabripinnis). Natural triploidy have also been reported for some species (Fauaz et al. 1994).

B chromosomes have been observed in several neotropical fish, from about 21 species of 8 families of Ostariphysi (Moreira-Filho 1994). For the genus Astyanax in particular, these chromosomes have been described in A. scabripinnis (Salvador and Moreira-Filho 1992, Maistro et al. 1992, Fauaz et al. 1994, Souza and Moreira-Filho 1995, Vicente et al. 1996, Mizoguchi and Martins-Santos 1997) and A. eigenmanniorum (Stripecke et al. 1985). B chromosomes are "additional dispensable chromosomes that are present in some individuals from some populations in some species, which have probably arisen from the A chromosomes but that follow their own evolutionary pathway" (Camacho 1993). Thus, B chromosomes are not required for the growth, development and reproduction. Among the known examples in fish, some cases are sporadic, as in Apareiodon piracicabae and Oligossarcus pintoi (Falcão et al. 1984). On the other hand, there are several situations in which these chromosomes are frequent in the populations, as in Rhamdia hilarii (Fenocchio and Bertollo 1990), Prochilodus lineatus (=scrofa) (Pauls and Bertollo 1993) and Astyanax scabripinnis (Salvador and Moreira-Filho 1992, Maistro et al. 1992, Souza and Moreira-Filho 1995, Vicente et al. 1996, Mizoguchi and Martins-Santos 1997). They can vary widely in size, ranging from macrochromosomes as in Astyanax scabripinnis (Salvador and Moreira-Filho 1992,

\footnotetext{
* Corresponding author, e-mail: omfilho@power.ufscar.br
} 
Maistro et al. 1992) to microchromosomes as in Moenkhausia sanctaefilomenae (Foresti et al. 1989) and Prochilodus lineatus (=scrofa) (Pauls and Bertollo 1993).

In the present study, a large metacentric B chromosome was analyzed in 3 Astyanax species, The available data support the suggestion that this chromosome had a remote origin in this fish group.

\section{Material and methods}

Specimens of Astyanax fasciatus from the São Francisco river (Três Marias, Minas Gerais State, Brazil), Astyanax schubarti from the Paraná river (Posadas, Misiones, Argentina), and Astyanax scabripinnis from the Pedras stream, (Campos do Jordão, São Paulo State, Brazil) were studied. Chromosome preparations were made following Moreira-Filho and Bertollo (1991b) and Bertollo et al. (1978). The nucleolar organizer regions (Ag-NORs) and constitutive heterochromatin were characterized according to Howell and Black (1980) and Sumner (1972).

\section{Results}

A. fasciatus ( 8 females, 2 males) showed a diploid number of $2 n=46$ chromosomes in 9 specimens and $2 n=47$ in one female specimen. A total of 498 cells were examined. The standard kary-

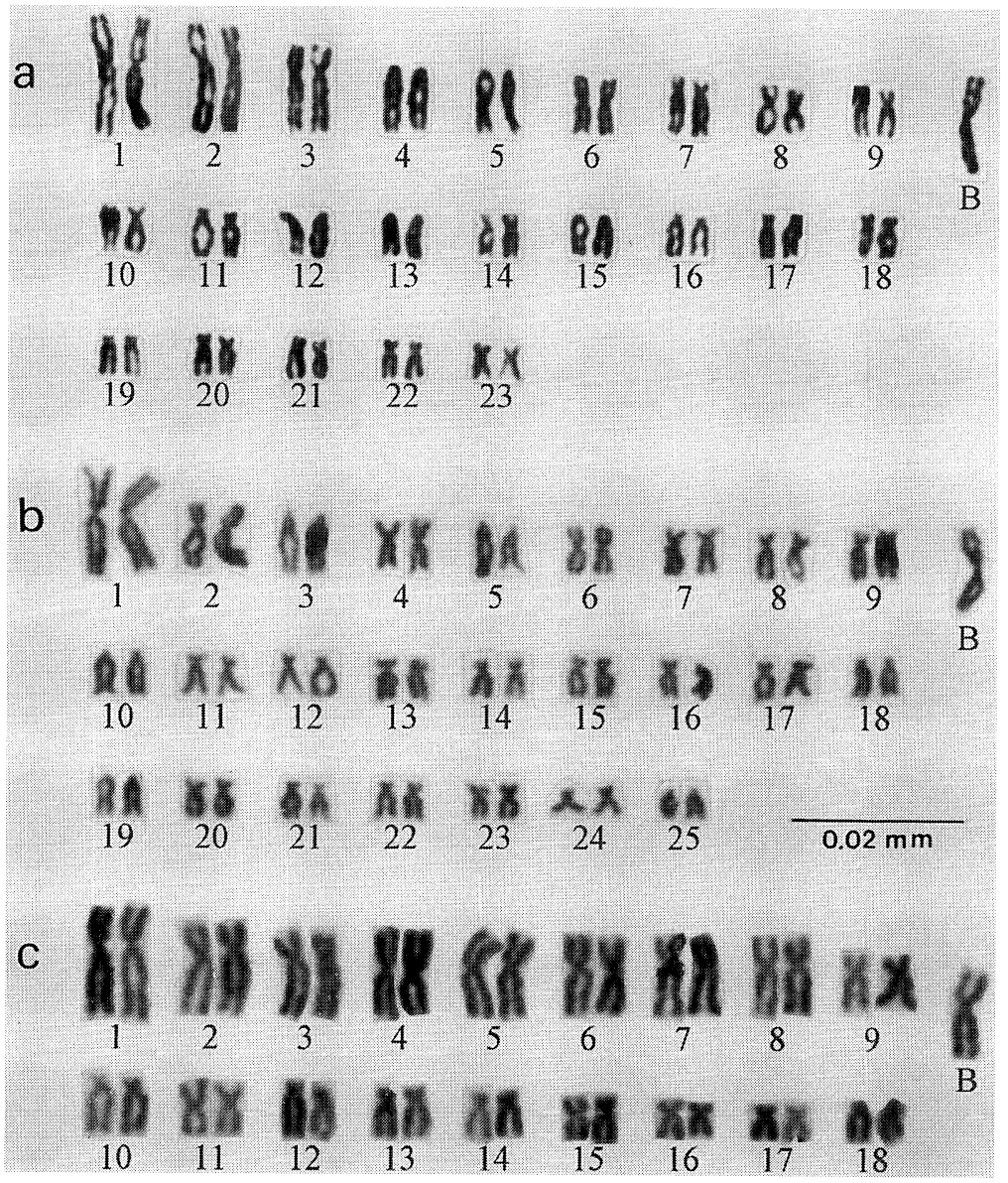

Fig. 1. Karyotypes of the 3 species studies. a) Astyanax fasciatus, $2 n=46+B$, b) Astyanax scabripinnis, $2 n=50+\mathrm{B}$, c) Astyanax schubarti, $2 n=36+\mathrm{B}$. 

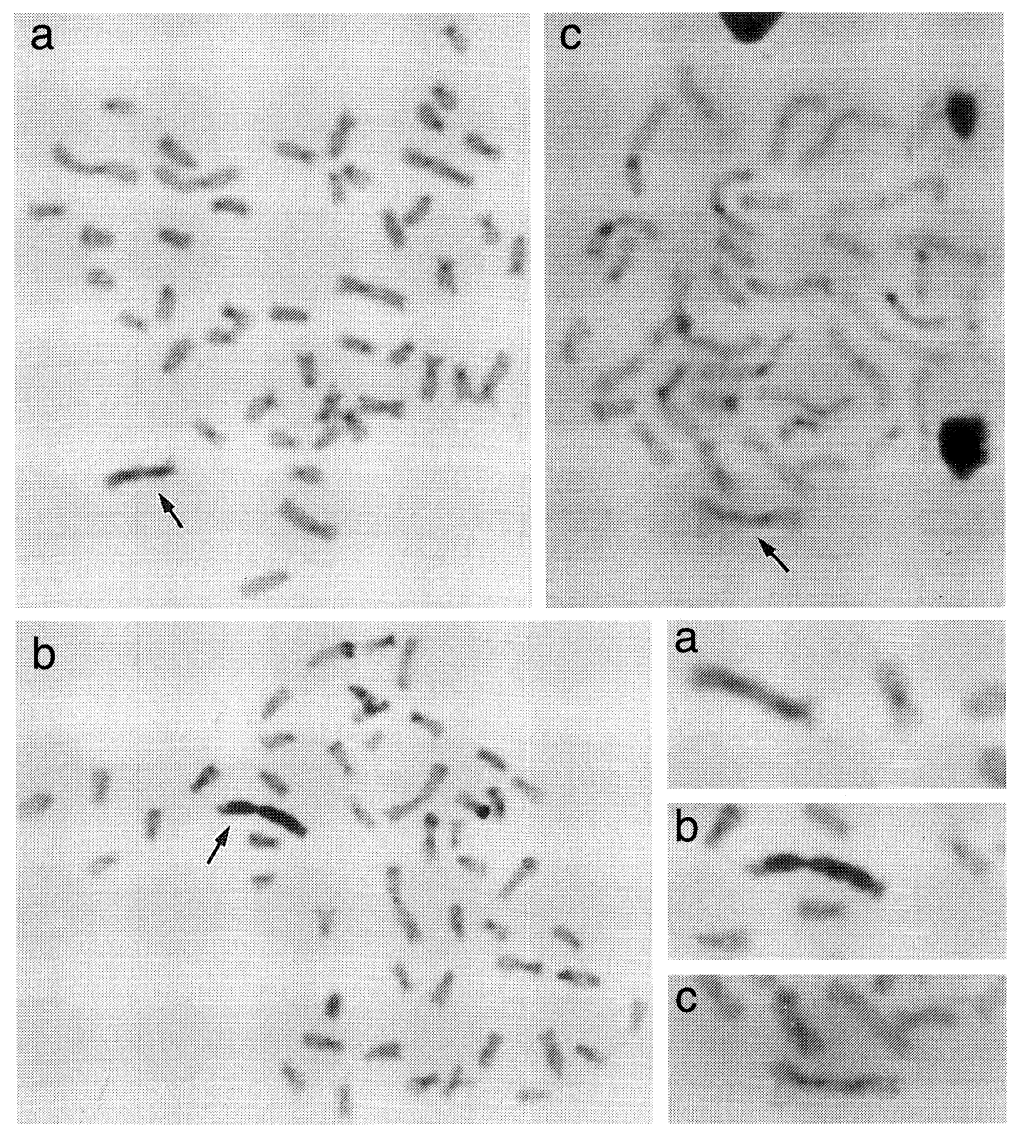

Fig. 2. C-banded metaphase chromosomes of a) Astyanax fasciatus, b) Astyanax scabripinnis, and c) Astyanax schubarti. B chromosomes are indicated by arrows and in details. Note the differences in the $\mathrm{C}$-banding pattern among the $\mathrm{B}$ chromosomes.

otype consists of $2 n=46$ chromosomes ( 6 metacentrics, 24 submetacentrics, 8 subtelocentrics, 8 acrocentrics), with a fundamental number (NF) equal to 84 . A large metacentric B chromosome was observed in all metaphases from the specimens that presented $2 n=47$ (Fig. 1a) and was found to be fully heterochromatic after C-banding (Fig. 2a).

A. scabripinnis (22 females, 10 males) also had different diploid numbers, for a total of 406 cells analyzed: $2 n=50$ in 4 specimens ( 2 females, 2 males), $2 n=51$ in 27 specimens ( 19 females, 8 males), and $2 n=52$ in one specimen (female). The standard karyotype for this species is made up $2 n=50$ chromosomes ( 6 metacentrics, 22 submetacentrics, 10 subtelocentrics, 12 acrocentrics), with a fundamental number equal to 88 . In $100 \%$ of the cells from the specimens that had $2 n=51$ and $2 n=52$ it was possible to observe 1 or 2 metacentric macrochromosomes $\mathrm{B}$, similar in size to pair number 1 in the complement (Fig. 1b). These chromosomes were found to be partially or totally heterochromatic after C-banding (Fig. 2b).

A. schubarti (13 females, 10 males, 6 specimens of undetermined sex) showed $2 n=36$ chromosomes in 21 specimens ( 12 females, 9 males), and $2 n=37$ in 8 specimens ( 5 females, 3 males), for a total of 610 cells examined. The standard karyotype consists of $2 n=36$ chromosomes (12 metacentric, 14 submetacentrics, 10 subtelocentrics), with a fundamental number equal to 72 . Again, in all cells from the 8 individuals with $2 n=37$ an extra chromosome of the large metacentric type was observed (Fig. 1c), also partially or totally heterochromatic (Fig. 2c). 


\section{Discussion}

Cytogenetic studies on A. scabripinnis have been intensified over the past years (Moreira-Filho and Bertollo 1991a, Maistro et al. 1998, Mizoguchi and Martins-Santos 1998, among others). Several populations of this species have a large metacentric B chromosome, similar in size to the first pair in the complement (Fig. 1b). Thus, Salvador and Moreira-Filho (1992) showed that $87 \%$ of the specimens from the Pedras stream (Campos do Jordão, São Paulo State, Brazil), including males and females present this chromosome. Maistro et al. (1992), studying A. scabripinnis from another locality (Araquá river, Botucatu, São Paulo State, Brazil), identified a B chromosome with a similar size and shape, but with a lower frequency about $27 \%$ and, with only females being carriers. Mizoguchi and Martins-Santos (1997), observed that this type of B chromosome was present only in $19 \%$ of the specimens from the Yukatan river (Maringá, Paraná State, Brazil), and again restrict to females. A complementary study in the Campos do Jordão region showed different frequencies for this chromosome in different populations of A. scabripinnis, and confirmed a high frequency of carriers among specimens from the Pedras stream (about 79\%) and lower frequencies among specimens from the Casquilho (39\%) and the Perdizes (22\%) streams, with a distortion in the sex ratio associated with the presence of Bs (Vicente et al. 1996). On the other hand Rocon-Stange and Almeida-Toledo (1993) and Mizoguchi and Martins-Santos (1997) reported a variation of 1 to 4 microchromosomes $\mathrm{B}$ in some other populations of $A$. scabripinnis.

A hypothesis that the large metacentric $\mathrm{B}$ chromosome of $A$. scabripinnis corresponds to an isochromosome originated from the long arm of the acrocentric 24th chromosome of the standard karyotype was proposed by Vicente et al. (1996) on the basis of their C-banding patterns. The localization by in situ hybridization of a characteristic satellite DNA in the pair 24, as well as in both chromosomal arms of the B chromosome (Mestriner et al. 2000), in association with studies of synaptonemal complexes (Dias 1995, Mestriner et al. 2000) evidenced the isochromosomal nature of these Bs. A simultaneous origin for the macro- and microchromosomes B from a subtelo/acrocentric chromosome through a centric misdivision appears to be as feasible hypothesis (Néo 1999), with a differential fixation and frequency of these different types of Bs among distinct populations of the species.

According to Moreira-Filho and Bertollo (1991a), A. scabripinnis forms small populations restricted to the headwaters of small tributaries, so that larger rivers representing ecological barriers against gene flow between distinct populations. In this sense, A. scabripinnis differs from $A$. schubarti and $A$. fasciatus, which occupy the main river channels, and form large shoals with migratory habits at spawning time. Accordingly, these 2 last species are not subject to barriers against gene flow.

As mentioned above, the metacentric macrochromosome $\mathrm{B}$ of $A$. scabripinnis is found to be fixed in various populations of this species in distinct hydrographic basins, and in sites that may be separated by distances of more than $600 \mathrm{~km}$. In addition, a similar extra chromosome was found in 3 other species of this genus, i.e., A. fasciatus, A. schubarti (Fig. 1a, c) and A. eigemnanniorum (Stripecke et al. 1985). However, it was observed only in few populations of these species.

The similarities in size and shape of the B chromosomes in the 4 Astyanax species, taken together with the distinct geographic distribution of the collection sites, suggest an ancient origin for this chromosome. In A. scabripinnis the $\mathrm{B}$ chromosome is an isochromosome (Mestriner et al. 2000), as discussed above. Further studies, similar to those carried out in A. scabripinnis, will be necessary to demonstrate if the large metacentric Bs of $A$. fasciatus and $A$. schubarti are also isochromosomes. This fact will be important to elucidate a common origin for these chromosomes.

The common occurrence of $\mathrm{B}$ chromosomes in some populations of $A$. scabripinnis may be related to some biological and/or ecological peculiarities, such as (1) the particular life habits of this species compared to those of the other 3 species of the same genus, (2) a founder effect, and (3) the 
conditions of some regions where the extent of predation and competition is lower, turning these environments more favorable for the populations and contributing to the maintenance of the $\mathrm{B}$ chromosomes. In this sense, B chromosomes even may not represent an advantage for their carriers; rather they may be characterized as opportunistic elements under more suitable environmental conditions for their fixation (Néo 1999).

\section{Acknowledgements}

This research was supported by FAPESP: Fundação de Amparo à Pesquisa do Estado de São Paulo and CNPq: Conselho Nacional de Desenvolvimento Científico e Tecnológico (Brazil), and Programa de Incentivos a Docentes Investigadores, Secretaria de Políticas Universitarias (Argentina). The authors are grateful to Dr. Yoshimi Sato (CODEVASF), for fish supplying.

\section{References}

Bertollo, L. A. C., Takahashi, C. S. and Moreira-Filho, O. 1978. Cytotaxonomic considerations on Hoplias lacerdae (Pisces, Erythrinidae). Brazil. J. Genet. 1: 103-120.

Camacho, J. P. M. 1993. Polymorphisms and Geographic Distribuition. In: 1st B-Chromosome Conference. Madrid, Spain. pp. 2-3.

Dias, A. L. 1995. Estudo do complexo sinaptonêmico em peixes, Prochilodus lineatus (Prochilodontidae) e Astyanax scabripinnis (Characidae): análise da sinápse dos cromossomos supranumerários. PhD Thesis. Universidade Federal de São Carlos, Brazil.

Falcão, J. N., Moreira-Filho, O. and Bertollo, L. A. C. 1984. An additional chromosome in two fish species. Brazil J. Genet 7: $109-118$.

Fauaz, G., Vicente, V. and Moreira-Filho, O. 1994. Natural triploidy and B chromosomes in the neotropical fish genus Astyanax (Characidae). Brazil. J. Genet. 7: 639-645.

Fenocchio, A. S. and Bertollo, L. A. C. 1990. Supernumerary chromosomes in a Rhamdia hilarii population (Pisces, Pimelodidade). Genetica 81: 193-198.

Foresti, F., Almeida-Toledo, L. F. and Toledo-Filho, S. A. 1989. Supernumerary chromosome system, C-banding pattern characterization and multiple nucleolus organizer regions in Moenkhausia sanctaefilomenae (Pisces, Characiadae). Genetica 79: 107-114.

Garuti, V. 1988. Morfologia, reprodução e aspectos evolutivos de Astyanax bimaculatus (Ostariophysi, Characidae) em cursos de água do rio Paraná. PhD Thesis, Universidade de São Paulo, Brazil.

Géry, J. 1977. Characoids of the World. T. F. H. Publications. 672 p.

Godoy, M. P. 1975. Peixes do Brasil: Subordem Characoidei. V. 1. Ed. Piracicabana. 216 p.

Howell, W. M. and Black, D. A. 1980. Controlled silver-staining of nucleolus organizer regions with a protective colloidal developper: a 1-step method. Experientia 36: 1014-1015.

Maistro, E. L., Foresti, F., Oliveira, C. and Almeida-Toledo, L. 1992. Occurrence of macro B chromosome in Astyanax scabripinnis paranae (Pisces, Characiformes, Characidae). Genetica 87: 101-106.

-, Oliveira, C. and Foresti, F. 1998. Comparative cytogenetics and morphological analysis of Astyanax scabripinnis paranae (Pisces, Characidae, Tetragonopterinae). Genet. Mol. Biol. 21: 201-206.

Mestriner, C. A., Galetti Jr., P. M., Valentini, S. R., Ruiz, I. R. G., Abel. L. D. S., Moreira-Filho, O. and Camacho, J. P. M. 2000. Structural and functional evidence that a B chromosome in the characid fish Astyanax scabripinnis is an isochromosome. Heredity 85: 1-9.

Mizoguchi, S. M. H. N. and Martins-Santos, I. C. 1997. Macro- and microchromosomes B in females of Astyanax scahripinnis (Pisces, Characidae). Hereditas 127: 249-253.

- and -. 1998. Cytogenetics and morphometric differences in populations of Astyanax scabripinnis (Pisces, Characidae) from Maringá region, PR, Brazil. Genet. Mol. Biol. 21: 55-61.

Moreira-Filho, O. 1994. Cromossomos Supranumerários em Peixes. In: V Simpósio de Citogenética Evolutiva e Aplicada de Peixes Neotropicais. Botucatu, Brazil. pp. 62-63.

- and Bertollo, L. A. C. 1991a. Astyanax scabripinnis (Pisces, Characidae): a species complex. Brazil. J. Genet. 14: $331-$ 357.

— and - 1991b. Extraction and use of the cephalic kidney for chromosome studies in small fish. Brazil. J. Genet. 14: 1085-1090.

Néo, D. M. 1999. Distribuição dos cromossomos B em Astyanax scabripinnis (Pisces, Characidae) ao longo do Ribeirão 
Grande, na região de Campos do Jordão, São Paulo. MSc Dissertation. Universidade Federal de São Carlos, Brazil. Pauls, E. and Bertollo, L. A. C. 1993. Evidence for a system of supernumerary chromosomes in Prochilodus scrofa Steindachner, 1881 (Pisces, Prochilodontidae). Caryologia 36: 307-314.

Rocon-Stange, E. A. and Almeida-Toledo, L. F. 1993. Supernumerary B chromosomes restricted to males in Astyanax scabripinnis (Pisces, Characidae). Brazil. J. Genet. 16: 601-615.

Salvador, L. B. and Moreira-Filho, O. 1992. B chromosomes in Astyanax scabripinnis (Pisces, Characidae). Heredity 69: $50-56$.

Souza, I. L. Moreira-Filho, O. 1995. Cytogenetic diversity in the Astyanax scabripinnis species complex (Pisces, Characidae). I. Allopatric distribution in a small stream. Cytologia 60: 1-11.

Stripecke, R., Nogueira-Pinto, M. T., Hackel, C. and Sazima, I. 1985. O Cariótipo de Astyanax eigenmanniorum (Osteichthyes, Characidae). In: XII Congresso Brasileiro de Zoologia. Campinas, Brazil. pp. 173-174.

Sumner, A. T. 1972. A simple technique for demonstrating centromeric heterochromatin. Exp. Cell Res. 75: 304-306.

Vicente, V. E., Moreira-Filho, O. and Camacho, J. P. M. 1996. Sex-ratio distortion associated with the presence of a B chromosome in Astyanax scabripinnis (Teleostei, Characidae). Cytogenet. Cell Genet. 74: 70-75. 